\title{
EASTERN KINGBIRD USE OF AN ATYPICAL NEST SITE IN SOUTHERN ALBERTA
}

ANDY M. BEZENER, \#412, 11104 - 84 Avenue, Edmonton, AB. T6G 2R4 and BRENDA DALE, Canadian Wildlife Service, Room 200, 4999-98 Avenue, Edmonton, AB. T6B 2X3

The Eastern Kingbird breeds throughout much of the United States and southern Canada. ${ }^{2}$ Within the grasslands region of southern Alberta this species is common to abundant ${ }^{9}$ and has been found to occupy a variety of nesting habitats ranging from agricultural shelterbelts, river valleys and wooded coulees, preferring scattered trees in open country that provide a sufficient food base. $^{10}$

Eastern Kingbirds typically select a nest site on a horizontal tree or shrub branch (usually deciduous) and usually well away from the trunk. ${ }^{1,4,5,6,7}$ The nest site may vary in vertical location from 2 to 60 feet above the ground, ${ }^{4,5}$ at an average height of 8 to 20 feet. $^{2}$ Murphy (1983) suggests that Eastern Kingbird nest site selection balances the need for nest protection from predators and from the weather.

On 3 July 1994 an Eastern Kingbird nest and brood was discovered in a solution pocket of a large sandstone boulder at Canadian Forces Base Suffield (proposed Suffield National Wildlife Area, longitude $110^{\circ}$ 24' 50", latitude $50^{\circ} 32^{\prime} 00^{\prime \prime}$, elevation $650 \mathrm{~m}$ A.S.L.), $30 \mathrm{~km}$ north of Medicine Hat, Alberta. An adult bird was initially observed at the nest site. Observations from atop a nearby boulder revealed a nest constructed of small twigs, fine native grasses, and other herbaceous material containing three visible nestlings. The nestlings were blind and downy white with orange-yellow mouths. More nestlings may have been concealed as the back of the nest was obscured from view.

The dimensions of the solution pocket, within which the nest cup was placed, were approximately 16 $\mathrm{cm}$ tall by $13 \mathrm{~cm}$ wide by $15 \mathrm{~cm}$ deep. The nest was approximately $2.5 \mathrm{~m}$ above the ground toward the upper right corner of the boulder's WSW facing side. The boulder itself had approximate dimensions of 3.0 $\mathrm{m}$ tall by $2.5 \mathrm{~m}$ wide by $3.5 \mathrm{~m}$ thick, and was supported at an angle in a hoodoo-like fashion by a gentle bentonite clay slope. The surrounding coulee habitat could be described as badlands topography, including the presence of sparse, low shrubs, bentonite clay slopes, tall sandstone cliffs, slumped material, and a small permanent stream draining into the South Saskatchewan River. Habitat found 300 to 400 metres further up the coulee could be considered more typical Eastern Kingbird nesting habitat with the presence of larger deciduous shrubs and trees including alder (Alnus spp.), birch (Betula spp.), and cherry (Prunus spp.), plus open slopes for foraging.

Both adult kingbirds remained mainly within $20 \mathrm{~m}$ of the nest and engaged in defensive behaviour that included silent observation, vocalization, and hovering above nearby shrubs and the nesting boulder. At 


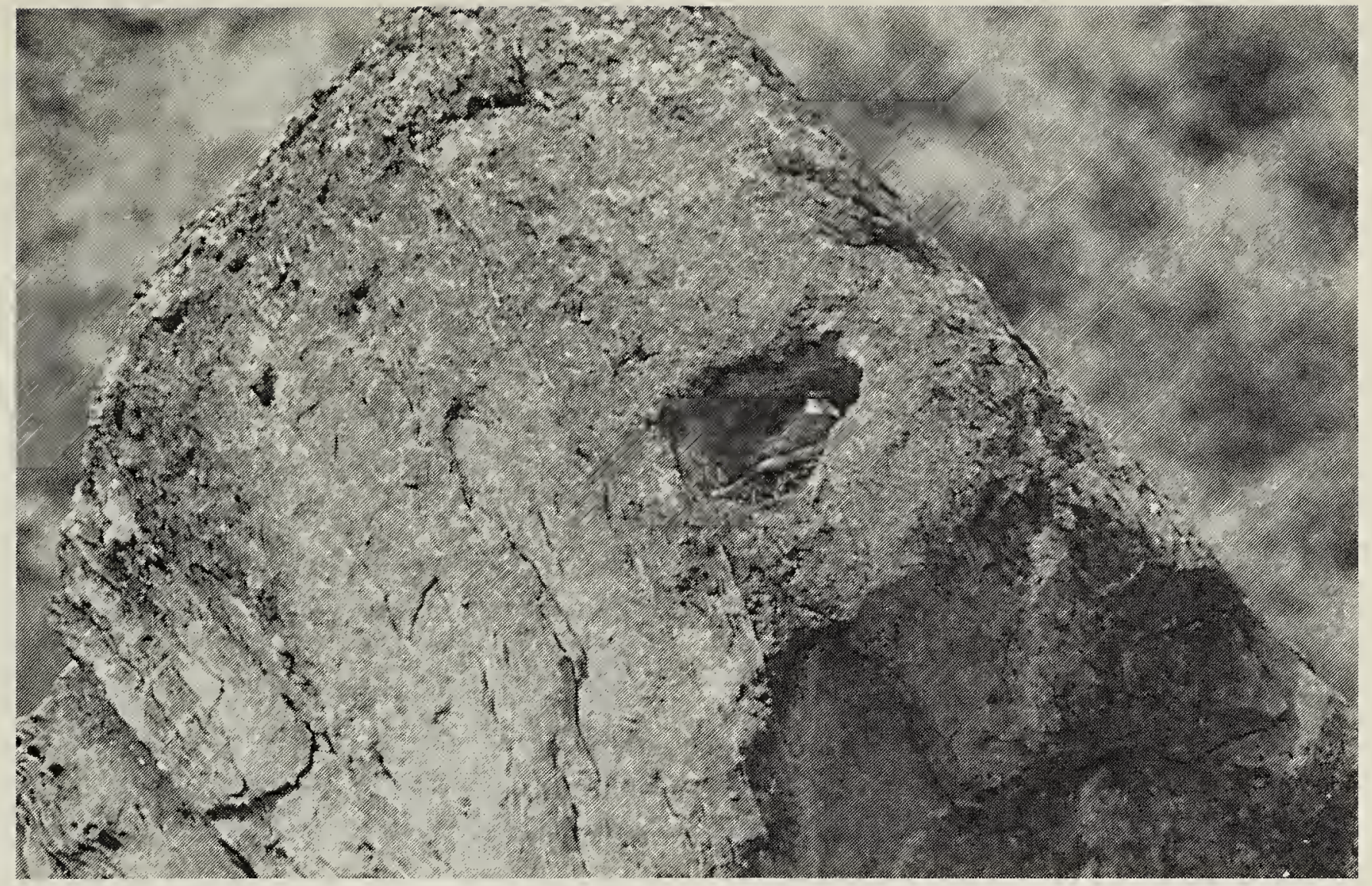

least one of the adults approached the nest with food and perched nearby but did not feed the young. Because of the apparent reluctance of the parents to feed the young in our presence, observations were terminated after 15 minutes.

A review of the literature failed to produce documentation of Eastern Kingbird use of boulders as potential nesting sites. However, the literature has documented other unusual Eastern Kingbird nesting sites including the inside of a gourd suspended from a pole, inside a rain gauge, in a reflector of an electric street light, inside confiscated Northern Oriole nests, ${ }^{1}$ inside fire-burned trees and snags, ${ }^{3}$ on stumps, fence posts, or upended tree roots. ${ }^{1,8,10}$

1. BENT, A.C. 1963. Life histories of North American flycatchers, larks, swallows, and their allies. United States National Museum Bulletin 179. Smithsonian Institution, Washington, DC.

2. GODFREY, W.E. 1966. The birds of Canada. National Museum of Canada. Bull. 203. Ottawa, Ontario.
3. HAMAS, M.J. 1983. Nest-site selection by Eastern Kingbirds in a burned forest. Wilson Bull. 95:475-77.

4. HARRISON, C. 1984. A field guide to the nests, eggs, and nestlings of North American birds. Collins, Toronto, Ontario.

5. HARRISON, H.H. 1979. A field guide to western birds' nests: of 520 species found breeding in the United States west of the Mississippi River. National Audubon Society. Pp. 119-21.

6. JOHNSGARD, P.A. 1979. Birds of the Great Plains: breeding species and their distribution. University of $\mathrm{Ne}$ braska Press. Lincoln, Nebraska.

7. MURPHY, M.T. 1983. Nest success and nestling habits of Eastern Kingbirds and other flycatchers. Condor 85:208-19.

8. PINKOWSKI, B.C. 1982. Western Kingbird nests in abandoned woodpecker cavity. Wilson Bull. 94:95-96.

9. SALT, W.R. and J.R. SALT. 1976 The birds of Alberta with their ranges in Saskatchewan and Manitoba. Hurtig Publishers, Edmonton, Alberta.

10. SEMENCHUK, G.P. 1992. The atlas of the breeding birds of Alberta. The Federation of Alberta Naturalists, Edmonton, Alberta. 